\title{
Pemetaan Pelanggan IndiHome Sebagai Daerah Sasaran Promosi (Studi Kasus : Witel Bandung)
}

\author{
Nisa Hanum Harani ${ }^{1}$, Cahyo Prianto ${ }^{2}$, Andri Fajar Sunandhar ${ }^{3}$ \\ Program Studi Teknik Informatika, Politeknik Pos Indonesia, Bandung, Indonesia ${ }^{1,2,3}$ \\ e-mail: nisahanum@poltekpos.ac.id ${ }^{1}$, cahyoprianto@poltekpos.ac.id ${ }^{2}$, \\ andrirrf7@gmail.com ${ }^{3}$
}

\begin{abstract}
Abstrak
Di era globalisasi ini, komunikasi pemasaran sangat penting untuk membantu meningkatkan promosi penjualan produk layanan digital indihome dengan memanfaatkan titik lokasi pelanggan yang menggunakan layanan indihome. Saat ini telah banyak sistem informasi yang digunakan untuk menunjang dan menyelesaikan suatu permasalahan dalam menentukan lokasi suatu tempat. Penentuan lokasi tersebut dapat dilakukan dengan menggunakan pemetaan. Pemetaan pelanggan indihome tersebut dilakukan dengan memanfaatkan peta yang sudah disediakan oleh google yakni Google Maps API berdasarkan alamat pelanggan layanan indihome. Oleh karena itu, dibutuhkan suatu sistem untuk mengetahui daerah mana yang paling banyak menggunakan layanan indihome, sehingga akan mempermudah sasaran promosi kepada pelanggan indihome yang belum menggunakan layanan add on indihome seperti Movin, Indihome Gamer, Indihome Musik, Indihome Study, Indihome Storage, Indihome Server, Video Call, dan paket add on lainnya. Hasil dari pemetaan ini dapat menentukan daerah/wilayah yang berpotensi untuk dilakukan promosi mengenai produk layanan add on indihome, sehingga akan berdampak pada peningkatan pelanggan dan pendapatan penjualan produk Add On.
\end{abstract}

Kata kunci: Google Maps API, Indihome, Pemetaan

\begin{abstract}
In this globalization era, marketing communication is very important to help increase sales promotion of indihome digital service products by utilizing customer location points that use indihome services. Currently there are many information systems that are used to support and solve problems in determining the location of a place. Determination of location can be done using mapping. The mapping of Indihome customers is done by utilizing a map provided by Google, the Google Maps API based on the address of the Indihome service customer. Therefore, we need a system to find out which areas use the most indihome services, so that it will make it easier to target promotions for indihome customers who have not used to add services to Indihome such as Movin, Indihome Gamers, Indihome Music, Indihome Music, Indihome Studies, Indihome Storage, Indihome Servers, Video Calls, and other additional packages. The results of this mapping can determine areas / regions that have the potential to be promoted in connection with the addition of indihome service products, so that it will have an impact on increasing customers and sales revenue of Add On products.
\end{abstract}

Keywords: Google Maps API, Indihome, Mapping

\section{Pendahuluan}

PT. Telkom adalah perusahaan BUMN yang menyediakan berbagai macam fasilitas komunikasi untuk memenuhi kebutuhan masyarakat tentunya dalam sektor information, telecomunication, edutainment and media yang merupakan pruduk dari indihome atau sering disebut dengan layanan triple-play yang terdiri dari telpon rumah, Internet on Fiber atau High Speed internet dan interaktif (UseeTV Cable) [1]. Indihome deilengkapi dengan berbagai layanan tambahan (add on) / paket-paket lainnya yang bisa dipilih sesuai dengan 
keinginan atau kebutuhan pelanggan [4]. Permasalahan yang terjadi yaitu bagaimana cara untuk memasarkan setiap produk tambahan pada layanan digital agar pelanggan indihome juga dapat berlangganan paket Add On yang tersedia karena saat ini yang berlangganan indihome rata-rata hanya memilih paket layanan Triple Play (3P) yaitu layanan berupa tv kabel, internet dan telepon atau paket layanan Dual Play (2P) internet dan telepon. Sehingga Telkom memiliki tantangan untuk memilih strategi promosi yang tepat supaya mampu meningkatkan pemahaman produk-produk tersebut kepada pelanggan [2]. Strategi promosi yang efektif dan tepat akan menarik keinginan pelanggan indihome yang belum berlangganan untuk berlangganan paket $A d d$ On lainnya [3].

Saat ini telah banyak sistem informasi yang digunakan untuk menunjang dan menyelesaikan suatu permasalahan dalam menentukan lokasi suatu tempat. Penentuan lokasi tersebut dapat dilakukan dengan menggunakan pemetaan. Pemetaan pelanggan indihome tersebut dilakukan dengan memanfaatkan peta yang sudah disediakan oleh google yakni Google Maps API. Dimana fitur Google Maps API digunakan untuk memetakan lokasi pelanggan yang sebelumnya sudah terpasang jaringan indihome [4], untuk memetakan lokasi pelanggan maka dibutuhkan sebuah koordinat dari setiap pelanggan, koordinat tersebut didapatkan berdasarkan titik lokasi rumah pelanggan berada. Peneliti mengambil data pelanggan indihome yang berada di Wilayah Telkom Bandung sebagai sampel penelitian. Kemudian Google Maps API di tampilkan dalam sebuah website dengan memanfaatkan class library [5].

Oleh karena itu, dibutuhkan suatu sistem untuk memberikan informasi terkait jumlah pelanggan indihome yang belum berlangganan paket $A d d$ On dan untuk mengetahui daerah mana yang paling banyak menggunakan layanan indihome, sehingga akan mempermudah sasaran promosi kepada pelanggan indihome yang belum berlangganan layanan add on indihome seperti Movin, Indihome Gamer, Indihome Musik, Indihome Study, Indihome Storage, Indihome Server, dan layanan add on lainnya. Hasil dari pemetaan ini dapat menentukan daerah/wilayah yang berpotensi untuk melakukan promosi mengenai produk layanan add on indihome lainnya, sehingga akan berdampak pada peningkatan pelanggan dan pendapatan penjualan produk paket add on. Sistem yang akan dibuat menggunakan bahasa pemrograman PHP [6] dengan menggunakan Framework CodeIgniter [7], database yang digunakan yaitu MySQL [8] dan Google Maps API [9] digunakan untuk memetakan lokasi pelanggan indihome. Metode pengembang sistem yang digunakan adalah dengan menggunakan metode Prototype. Sistem informasi ini dapat diakses oleh admin dan user, dimana admin bertugas sebagai pengelola sistem dengan memiliki hak akses penuh terhadap sistem seperti input/update data dan manajemen data user, sedangkan yang membedakan user tidak dapat melakukan input/update data dan manajemen data user.

\subsection{Promosi}

\section{Kajian Pustaka}

Promosi yaitu berbagai macam kegiatan yang dikendalikan oleh perusahaan untuk mengkomunikasikan keunggulan suatu produk dan menunjuk konsumen untuk membelinya. Hal tersebut telah menggambarkan bahwa kegiatan utama dalam memasarkan produk adalah promosi [2]. Dalam mempertahankan kontinuitas serta meningkatkan kualitas penjualan maka diperlukan promosi, dikarenakan promosi merupakan salah satu kegiatan penting bagi perusahaan dalam memasarkan produknya [10]. 


\subsection{Sistem Informasi}

Sistem informasi merupakan sebuah sistem yang dibuat oleh manusia, secara umum terdiri dari sekumpulan komponen berbasis komputer dan manual yang dibuat untuk mengelola, menghimpun dan menyimpan data serta menyediakan informasi terkait keluaran (output) kepada para penggunanya. Sistem informasi adalah suatu sistem yang saling berintegrasi dan berkaitan satu samalain dengan bertujuan menyediakan berbagai macam informasi sebagai pendukung sistem. Berikut merupakan beberapa kegiatan di dalam Sistem Informasi diantaranya [11]:

1. Input, merupakan suatu kegiatan yang menyediakan data supaya bisa di proses.

2. Proses, menggambarkan suatu data yang sedang di proses sehingga menghasilkan sebuah informasi.

3. Output, merupakan sebuah keluaran yang berupa informasi dari hasil proses.

4. Penyimpanan, media yang memelihara dan menyimpan berbagai macam data.

5. Kontrol, merupakan sebuah kegiatan yang mengontrol jalannya sistem tersebut.

\subsection{Pemetaan}

Pemetaan merupakan tahapan yang harus dilakukan dalam pembuatan peta untuk menentukan lokasi suatu tempat. Langkah pertama yang harus dilakukan dalam pembuatan pemetaan yaitu pengumpulan data dilanjutkan dengan pengolahan data dan penyajian dalam bentuk peta. Berdasarkan pengertian tersebut, pemetaan menjadi solusi dalam menginformasikan lokasi dari suatu tempat berdasarkan data-data yang diolah oleh sistem[12].

\subsection{Google Maps API}

Google Maps merupakan layanan aplikasi dan teknologi peta berbasis web yang disediakan oleh Google. Saat ini Google Maps merpakan layanan pemetaan berbasis web yang sedang populer, karena bisa menambahkan layanan Google Maps ke website dengan menggunakan Google Maps API. Google Maps API bisa ditambahkan ke website kita menggunakan JavaScript. Aplication Programming Interface (API) adalah sekumpulan perintah, fungsi, class dan protokol yang memungkinkan suatu software berhubungan dengan software lainnya. Pengetahuan yang diperlukan untuk mengembangkan Google Maps API adalah tentang HTML dan JavaScript, sedangkan peta sudah disediakan oleh google [13].

\subsection{Metode Prototype}

Prototype merupakan perangkat lunak versi awal dari suatu sistem yang digunakan untuk percobaan perancangan, mendemonstrasikan konsep-konsep, dan menemukan masalah dan solusi yang memungkinkan. Sistem prototype ini mengijinkan penggunanya untuk bisa mengetahui bagaimana sistem tersebut berjalan dengan baik. Tujuan penggunaan metode prototyping dalam penelitian ini supaya peneliti mendapatkan informasi/gambaran mengenai aplikasi yang akan dibangun dengan tahap pembangunan aplikasi prototype yang kemudian akan di evaluasi oleh user. Setelah aplikasi di evaluasi oleh user maka selanjutnya akan dijadikan acuan untuk pembuatan aplikasi yang akan dijadikan produk sebagai output dari penelitian ini. Berikut merupakan beberapa kelebihan menggunakan metode prototyping [14]:

1. Pengembang sistem dengan user akan saling berkomunikasi dalam hal penyamaan model sistem yang kemudian akan dijadikan dasar dari pengembangan sistem operasionalnya, 
2. Dalam menentukan model sistem dan operasionalnya user ikut terlibat aktif sehingga sistem yang dibuat bisa sesuai dengan harapan dan keinginan user,

3. Sistem yang dibangun mempunyai kualitas yang diharapkan karena sesuai dengan kebutuhan yang ada.

\subsection{Hypertext Preprocessor (PHP)}

PHP merupakan salah satu jenis scripting language yang dapat dieksekusi pada sisi server, atau biasa disebut dengan server-side scripting yaitu salah satu pemrograman yang paling populer yang sering dilihat di internet. Fasilitas $P H P$ merupakan integrasinya dengan mesin database yang membuat halaman dengan dukungan database dengan mudah. PHP termasuk ke dalam HTML-embedded, yang artinya code $p h p$ dapat kita sisipkan pada sebuah halaman $H T M L$. Untuk dapat mengetahui bahwa baris $H T M L$ tersebut merupakan script php maka biasanya menggunakan pasangan tag. Tag yang dapat digunakan untuk menyatakan script PHP adalah[15]:
a. $\langle$ ? ...? ?>
b. $\langle \% \ldots \%>$
c. $\langle$ ?php ... ?>

\subsection{Framework}

Framework adalah sekumpulan intruksi yang digabungkan menjadi satu dalam suatu class dan function. Fungsi tersebut dapat membantu untuk memudahkan develover dalam hal pemanggilan tanpa harus menuliskan kembali syntax yang sama secara berulang sehingga dapat meningkatkan efektifitas waktu pembuatan program [16].

\subsection{Codeigniter}

CodeIgniter merupakan salah satu framework php dengan sifat open source dan menggunakan metode MVC (Model, View, Controller) dimana memungkinkan pemisahan antara layer application-logic dan presentation. Dengan konsep MVC ini maka kode PHP, query Mysql, Javascript dan CSS bisa dipisah-pisahkan sehingga ukuran file menjadi lebih kecil dan lebih mudah dalam maintenance dan perbaikan kedepannya. Berikut adalah penjelasan dari konsep M-V-C [16]:

a. Model merupakan sebuah kode program yang memiliki hubungan dengan database sekaligus bisa memanipulasinya seperti inptut, edit, delete.

b. View merupakan kode program yang mengatur suatu tampilan pada aplikasi.

c. Controller merupakan kode program yang mengatur model dan view supaya bisa saling berkomunikasi.

\section{$2.9 \quad M y S Q L$}

MySQL merupakan suatu jenis database server yang sangat terkenal. $M y S Q L$ termasuk jenis Relational Database Manajement System (RDBMS). MySQL mendukung bahasa pemrograman $P H P$, bahasa permintaan yang terstruktur, karena pada penggunaannya $S Q L$ memiliki berberapa aturan yang telah distandarkan oleh asosiasi yang bernama ANSI. MySQL merupakan Relational Database Manajement System (RDBMS) server. RDBMS adalah program yang memungkinkan pengguna database untuk membuat, mengelola, dan menggunakan data pada suatu model relational [17]. 


\section{Metode Penelitian}

Metodelogi penelitian adalah sekumpulan kegiatan, prosedur, dan peraturan yang digunakan oleh orang yang akan melakukan analisi. Penelitian merupakan suatu kegiatan penyelidikan yang sistematis untuk dapat meningkatkan sejumlah pengetahuan, juga merupakan suatu usaha yang sistematis dan terorganisasi untuk menyelidiki masalah tertentu yang memerlukan jawaban atau solusi. Dalam penelitian ini penulis menggunakan metode pengembang sistem yaitu metode prototype.

Metode prototype digunakan untuk menjelaskan kebutuhan pengguna secara lebih rinci karena pengguna sering mengalami kesulitan dalam penyampaian kebutuhan secara detail tanpa melihat gambaran yang jelas. Untuk mengantisipasi agar proyek aplikasi dapat berjalan sesuai dengan rencana dan tepat waktu, maka sebaiknya spesifikasi kebutuhan sistem harus sudah disepakati terlebih dahulu oleh pengembang dan pengguna. Proses untuk menghasilkan prototype disebut Prototyping, berikut adalah tahapan metode prototyping [14]:

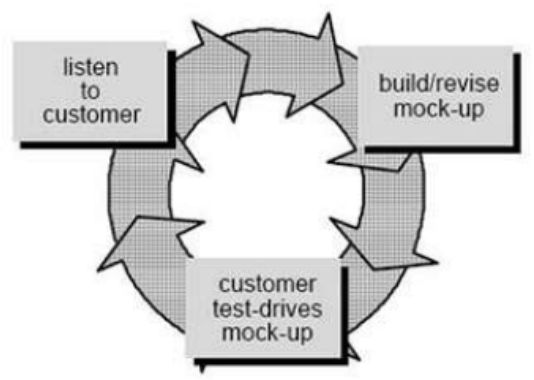

Gambar 1. Prototyping Model

Pada Gambar 1. merupakan gambaran proses dari prototyping, yang menjelaskan bahwa pertama kali untuk memulai prototype, yaitu dengan mendengarkan masukan dan kebutuhan dari pengguna. Pengguna dan pengembang harus bertemu dan membicarakan bersama-sama untuk menentukan tujuan dalam pengembangan sistem yang akan dibangun, sehingga pengembang bisa mengidentifikasi persyaratan yang diperlukan. Selanjutnya pengembang akan membuat sebuah gambaran yang berfokus pada representasi aspekaspek aplikasi yang kemudian akan dilihat dan di presentasikan kepada user. Berikut alur proses metode prototyping :

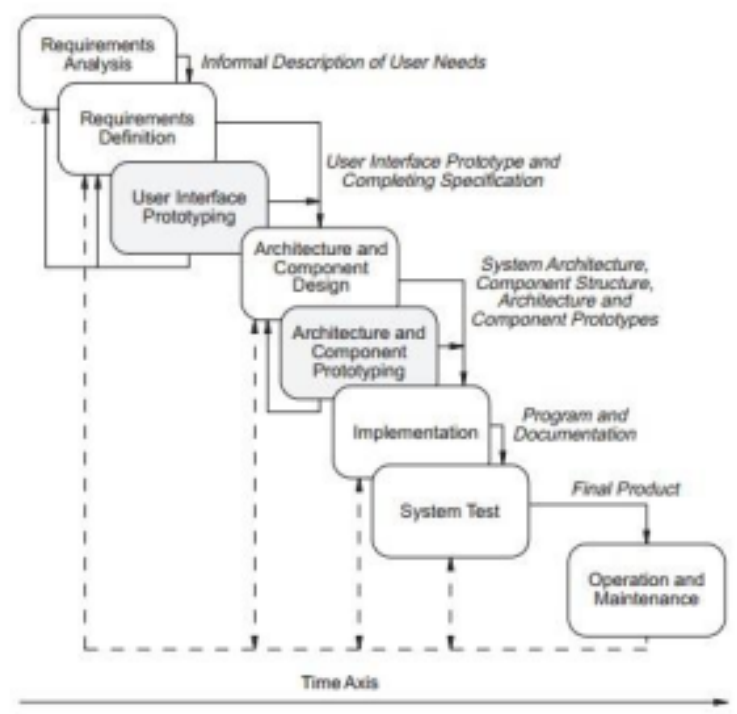

Gambar 2. Alur Proses Metode Prototyping 
Pada Gambar 2. merupakan alur proses dalam pengembangan sistem dengan menggunakan metode prototyping. :

1. Informal Description of User Needs

Pada tahap pertama, pengembang melakukan analisis kebutuhan user. Sekaligus menganalisis data yang akan digunakan, data yang digunakan sebagai sample penelitian yaitu data pelanggan Indihome Witel Bandung.

\section{User Interface Prototype and Completing Specification}

Pada tahap kedua setelah menganalisis data yang akan digunakan kemudian pengembang akan membuat prototype dari aplikasi yang akan dibangun, dengan merancang user interface kemudian dilanjutkan hingga penyusunan komponen-komponen dan arsitektur yang berkaitan dengan aplikasi yang akan dibangun.

3. System Architecture, Component Structure. Architecture and Component Prototypes

Pada tahap ini merupakan proses pengembangan sistem sehingga aplikasi akan dibangun sesuai dengan prototype yang sudah dibuat sebelumnya.

4. Program and Documentation

Selanjutnya aplikasi yang telah berhasil dibuat kemudian pada tahap ini akan dilakukan proses pengujian terhadap aplikasi tersebut sebelum digunakan oleh perusahaan, apabila saat pengujian aplikasi terdapat masalah maka tidak bisa melanjutkan ke tahap selanjutnya sehingga permasalahkan tersebut harus diselesaikan terlebih dahulu untuk melanjutkan pada tahap berikutnya.

5. Final Product

Pada tahap final product ini menyatakan bahwa aplikasi sudah sesuai dengan kebutuhan dan siap untuk digunakan.

\section{Hasil dan Pembahasan}

Sistem yang diusulkan adalah sistem prospek sales berbasis web. Website ini dibangun menggunakan bahasa pemrograman PHP, HTML, MySQL, Framework CodeIgniter, Javascript, Jquery, CSS. Terdapat dua user yang dapat mengakses website ini, yaitu user Admin dan user Pegawai. Untuk mengakses sistem, user dalam hal ini adalah user yang harus melakukan login terlebih dahulu dengan menggunakan NIK dan Password yang telah terdaftar pada aplikasi. Berikut adalah penjelasan dari Use Case Diagram dan implementasi:

\subsection{Use Case Diagram}

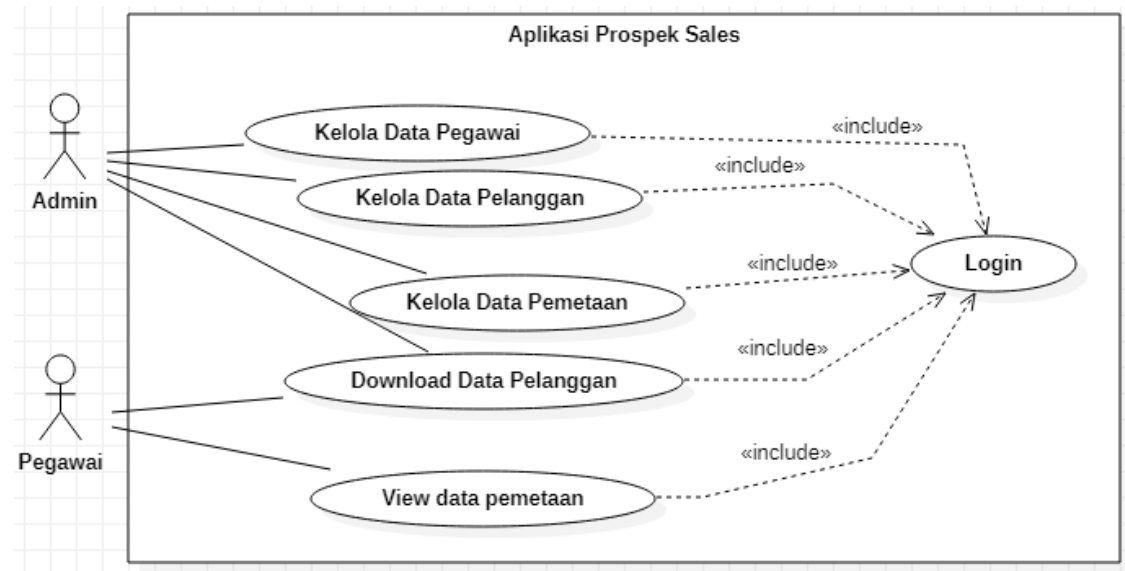

Gambar 3. Use Case Diagram Aplikasi Prospek Sales 
Pada Gambar 3 menggambarkan aktivitas atau urutan interaksi yang saling berkaitan diantara aktor dan sistem.

\subsubsection{Definisi Aktor}

Pada definisi aktor akan menjelaskan aktor-aktor yang terlibat dalam aplikasi adalah sebagai berikut :

Tabel 1. Definisi Aktor

\begin{tabular}{|c|l|l|}
\hline No. & Aktor & \multicolumn{1}{|c|}{ Deskripsi } \\
\hline 1 & Admin & a. Login \\
& & b. Kelola Data Pegawai \\
& & c. Kelola Data Pelanggan \\
& & d. Kelola Data Pemetaan \\
& & e. Download Data Pelanggan \\
\hline 2 & Pegawai & a. Login \\
& & b. Download Data Pelanggan \\
& & c. View Data Pemetaan \\
\hline
\end{tabular}

\subsubsection{Definisi Use Case}

Use Case yaitu sebuah teknik untuk merekam persyaratan fungsional sebuah sistem yang akan dibbangun. Use Case akan mendeskripsikan interaksi antara para pengguna dengan sistem, dengan memberikan sebuah narasi tentang bagaimana sistem tersebut digunakan.

Tabel 2. Definisi Use Case

\begin{tabular}{|c|c|c|}
\hline No. & Use Case & Deskripsi \\
\hline 1 & Login & $\begin{array}{l}\text { a. Menampilkan form login } \\
\text { b. Mengimputkan username dan } \\
\text { password }\end{array}$ \\
\hline 2 & Kelola Data Pegawai & $\begin{array}{l}\text { a. Menampilkan Data User } \\
\text { b. Mengelola Data User }\end{array}$ \\
\hline 3 & Kelola Data Pelanggan & $\begin{array}{l}\text { a. Download Data Pelanggan dari } \\
\text { dashboard telkom } \\
\text { b. Upload Data Pelanggan di } \\
\text { aplikasi prospek sales }\end{array}$ \\
\hline 4 & Kelola Data Pemetaan & $\begin{array}{l}\text { a. Input Nomor internet pelanggan } \\
\text { untuk pemetaan } \\
\text { b. Menampilkan Data Pemetaan }\end{array}$ \\
\hline 5 & Download Data Pelanggan & $\begin{array}{l}\text { a. Download data yang tidak } \\
\text { berlangganan }\end{array}$ \\
\hline 6 & View Pemetaan & $\begin{array}{l}\text { a. Meliihat data pelanggan dari } \\
\text { hasil pemetaan di maps sebagai } \\
\text { sasaran promosi }\end{array}$ \\
\hline
\end{tabular}




\subsection{Implementasi Sistem}

Implementasi Sistem merupakan prosedur atau langkah-langkah dalam menyelesaikan sebuah desain yang sebelumnya telah disetujui, sehingga dapat membuat sistem yang baru atau memperbaiki sistem yang sudah ada untuk dikembangkan. Tahap implementasi sistem ini merupakan tahap menerapkan sistem supaya sistem dapat dinyatakan siap untuk dioperasikan. Langkah-langkah tahap implementasi, yaitu penerapan rencana implementasi, proses kegiatan dalam melakukan implementasi, dan menindak lanjuti kegiatan implementasi.

\subsubsection{Tujuan Implementasi}

Adapun tujuan dari implementasi sistem ini, yaitu : mengkaji rangkaian sistem yang terdiri dari software maupun hardware untuk sarana penyajian informasi dan pengolahan data, menyelesaikain perancangan sistem yang sebelumnya telah disetujui atau berada dalam dokumen sistem yang baru, memastikan bahwa pengguna bisa menjalankan sistem dengan mudah terhadap sistem yang baru sehingga mendapatkan informasi yang baik dan jelas, memasitikan sistem yang telah dibuat sudah memenuhi permintaan pengguna, menguji sistem secara menyeluruh untuk memasitikan bahwa sistem telah berjalan dengan baik dan lancar.

\subsubsection{Implementasi Antarmuka}

Berdasarkan perancangan yang telah dibuat, didapat hasil dari implementasi yang menjadi tujuan pembuatan perangkat lunak ini yaitu dapat melihat jumlah pelanggan indihome yang tidak berlangganan paket add on dan dapat melihat lokasi pelanggan indihome pada peta/maps sebagai sasaran promosi, berikut adalah tampilan dari aplikasi Prospek Sales :

1. Halaman Login Admin/Pegawai

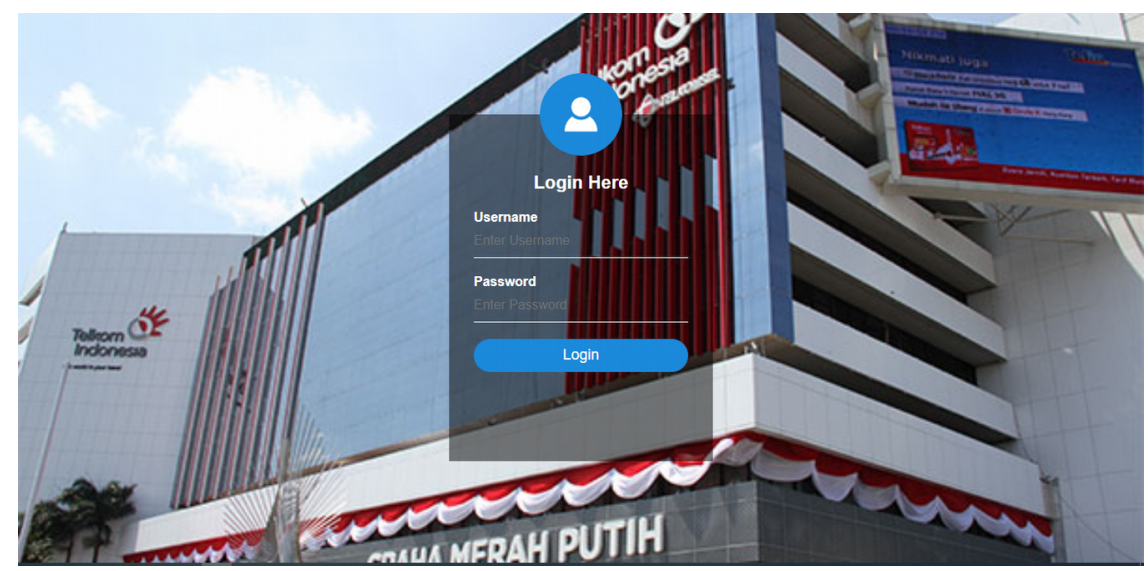

Gambar 4. Halaman Login Admin/Pegawai

Pada Gambar 4 adalah tampilan login admin/pegawai pada aplikasi prospek sales. Pada tampilan login admin/pegawai harus memasukkan data username dan password. 
2. Halaman Dashboard Admin

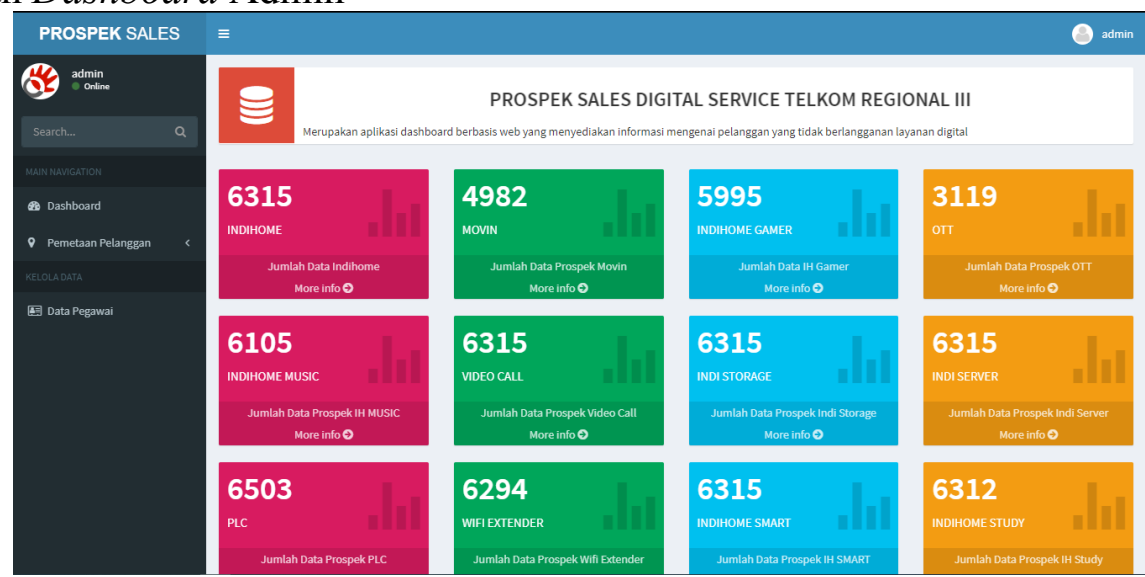

Gambar 5. Halaman Dashboard Admin

Pada Gambar 5 dapat dilihat jumlah pelanggan indihome dan jumlah pelanggan yang tidak berlangganan paket add on seperti Movin, Indihome Gamer, Ott, Indihome Music, dan paket add on lainnya.

3. Halaman Peta Pelanggan

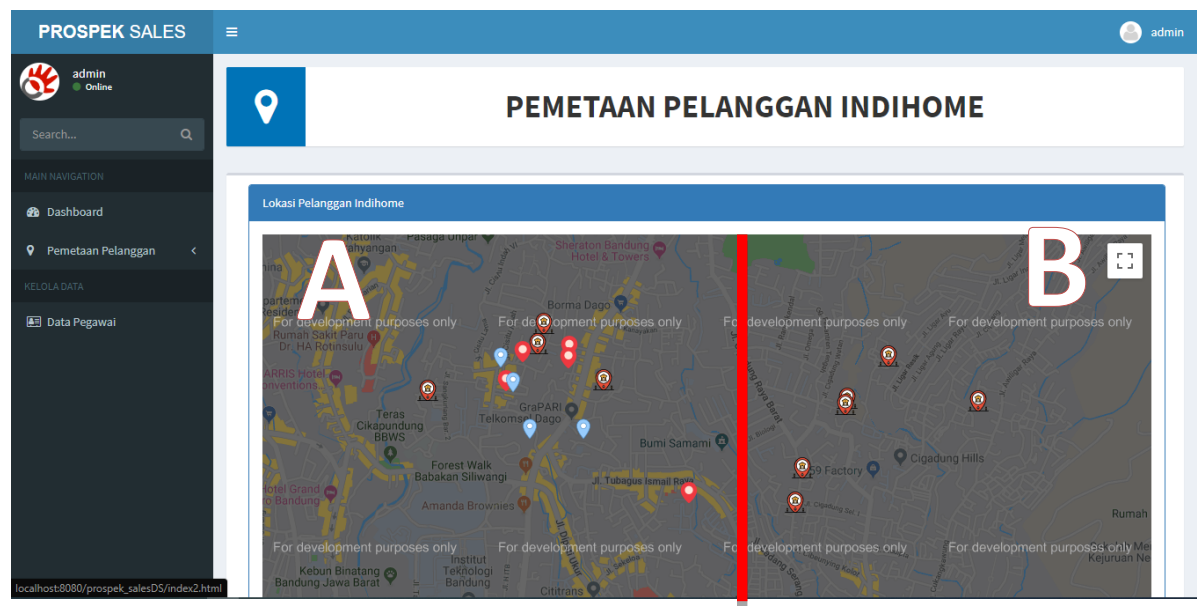

Gambar 6. Halaman Peta Pelanggan

Pada Gambar 6 adalah bagian pemetaan pelanggan indihome untuk dijadikan sasaran promosi kepada pelanggan indihome yang belum berlangganan paket add on . Terlihat pada Gambar 6 dimana wilayah A terdapat pelanggan indihome yang diberi icon berwarna coklat, icon orange Movin, dan icon biru Indihome Gamer. Di wilayah A tersebut pelanggan indihome sebagian besar sudah berlangganan paket add On, sedangkan di wilayah B hanya terlihat icon berwarna coklat yaitu pelanggan indihome. Pada wilayah B tersebut pelanggan indihome banyak yang belum berlangganan paket add on sehingga bagus untuk dijadikan sasaran promosi untuk menawarkan paket add on kepada pelanggan indihome yang belum berlangganan. 
4. Halaman Data Pegawai

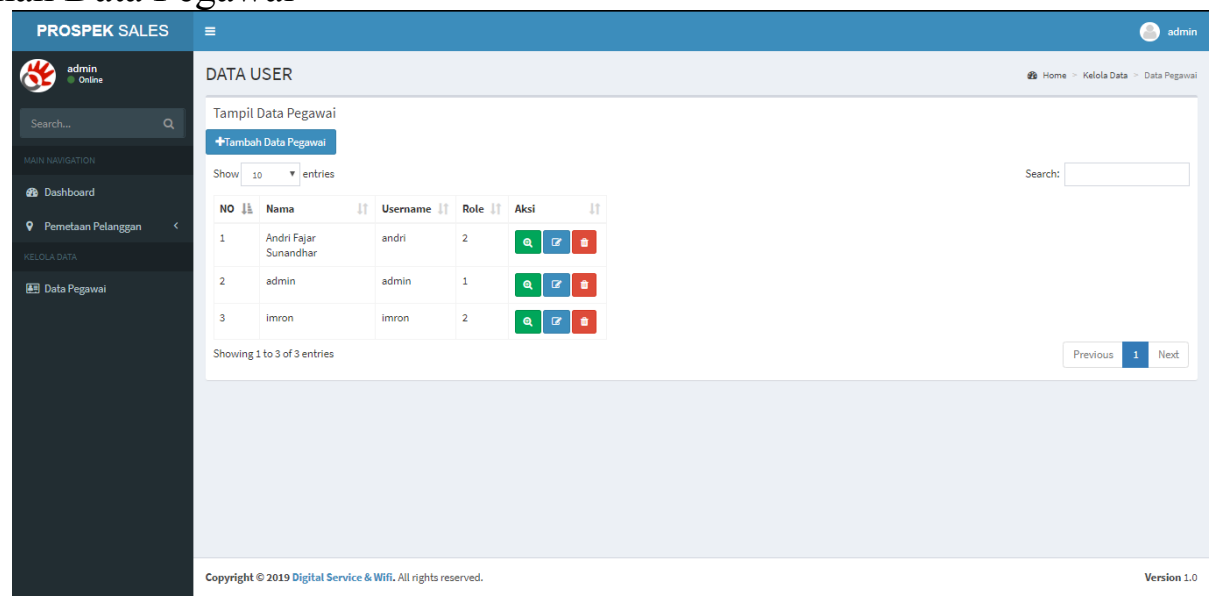

Gambar 7. Halaman Data Pegawai

Gambar 7 merupakan halaman data pegawai sekaligus pembuatan akun untuk pegawai oleh Admin.

5. Halaman Indihome Admin

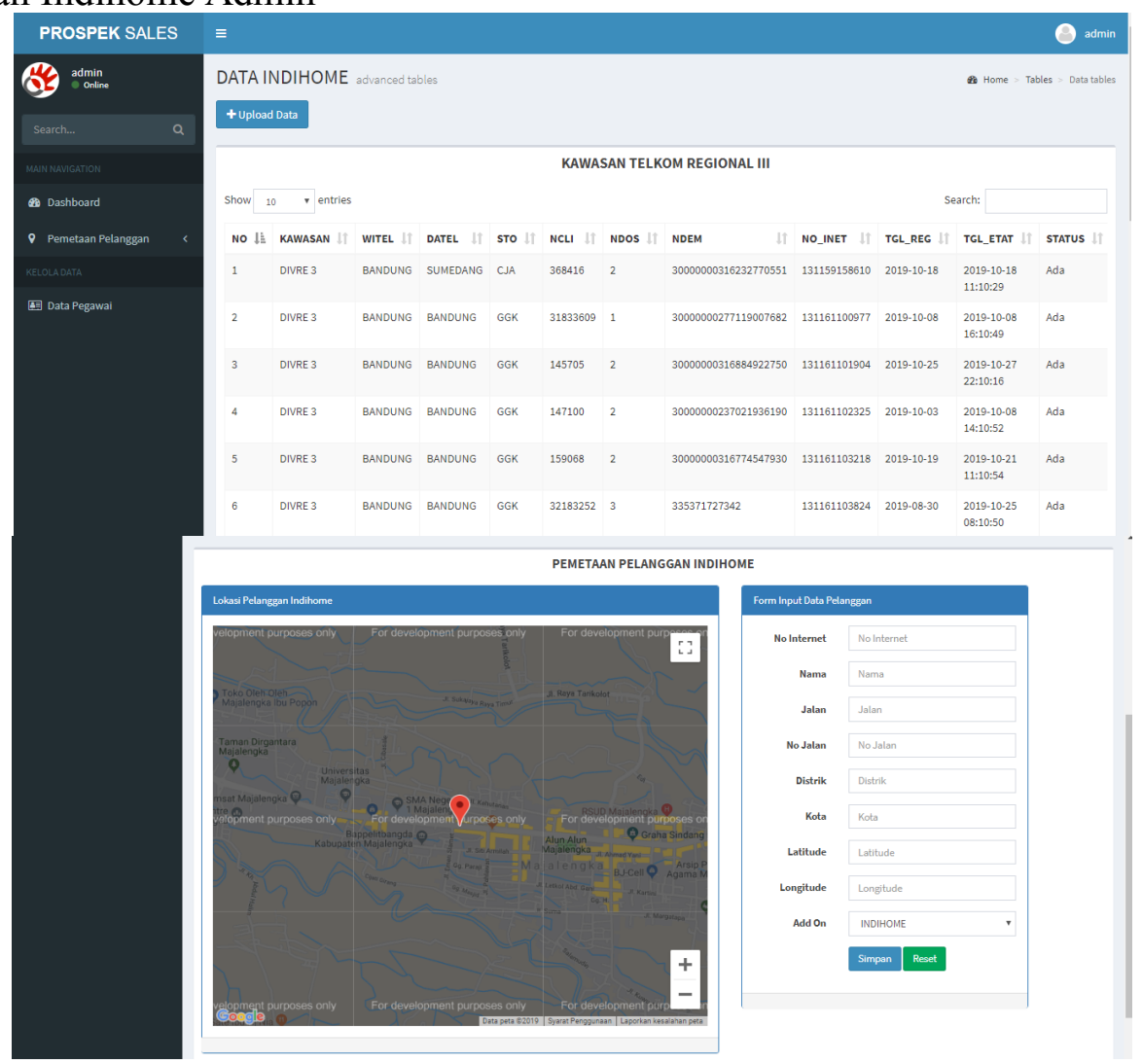

Gambar 8. Halaman Indihome Admin

Pada Gambar 8 terdapat tabel data pelanggan indihome yang sudah di upload dan penginputan data pelanggan untuk di petakan pada maps. Caranya pada data pelanggan indihome tersebut ada no_inet, no_inet tersebut di inputkan pada bagian pemetaan maka data akan otomatis ter isi kecuali bagian latitude dan longitude masih dengan cara manual, apabila sudah ter isi kemudian save maka lokasi pelanggan tersebut akan tampil pada maps 
(Dapat dilihat di Gambar 6). Pada tabel tersebut terdapat status (ada dan tidak ada), (ada) menjelaskan bahwa no_inet tersebut sudah berhasil di inputkan pada bagian pemetaan, sedangkan (tidak ada) belum di inputkan.

6. Halaman Paket Add On Admin

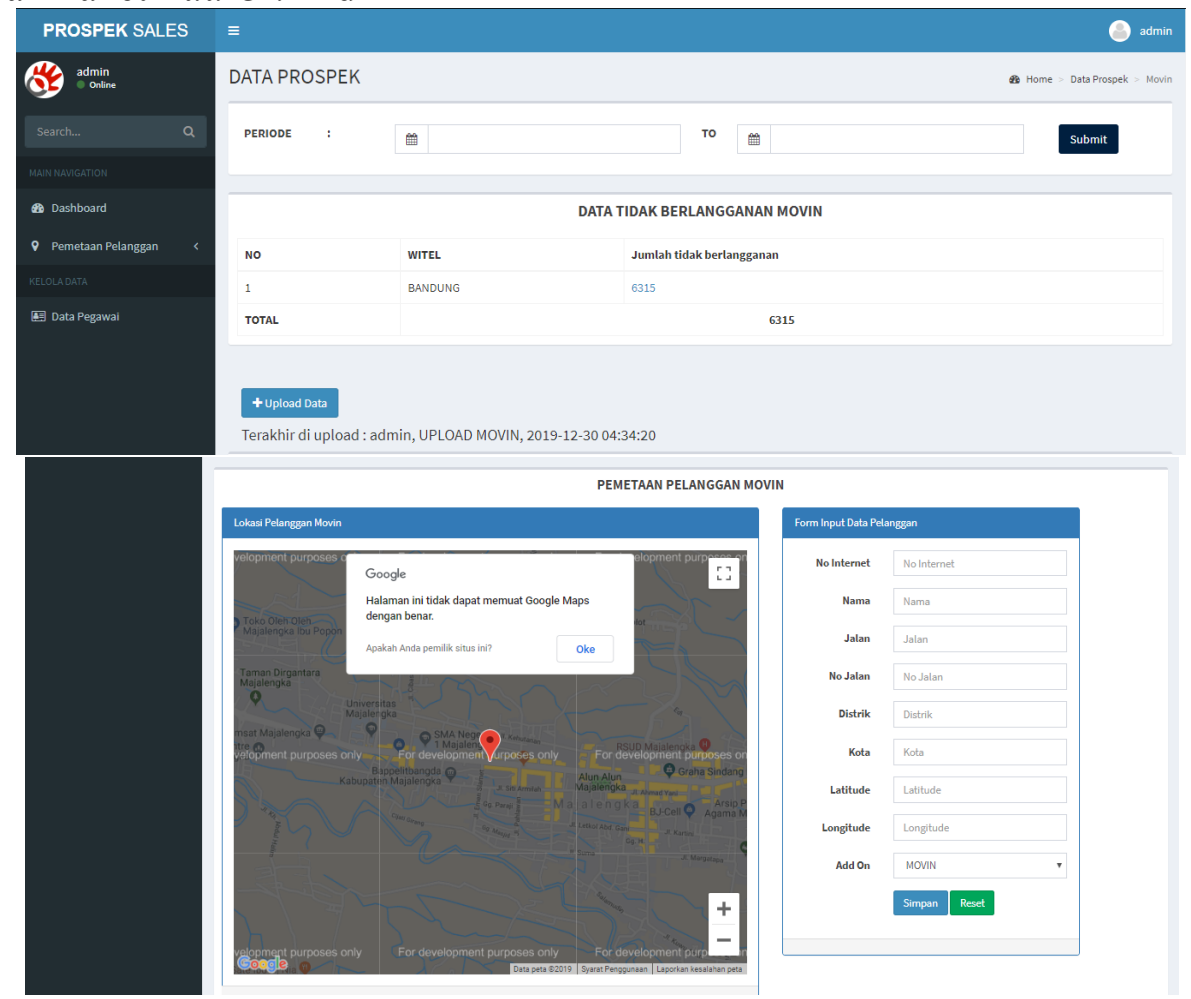

Gambar 9. Halaman Paket Add On Admin

Pada Gambar 9 yaitu halaman data pelanggan paket add on. proses penginputan pemetaannya sama seperti Gambar 8, yang membedakan pada Gambar 9 terdapat periode dimana dapat melihat jumlah pelanggan yang tidak berlangganan berdasarkan tanggal dan jumlah pelanggan tersebut bisa langsung di download pada angka yang berwarna biru.

7. Halaman Dashboard Pegawai

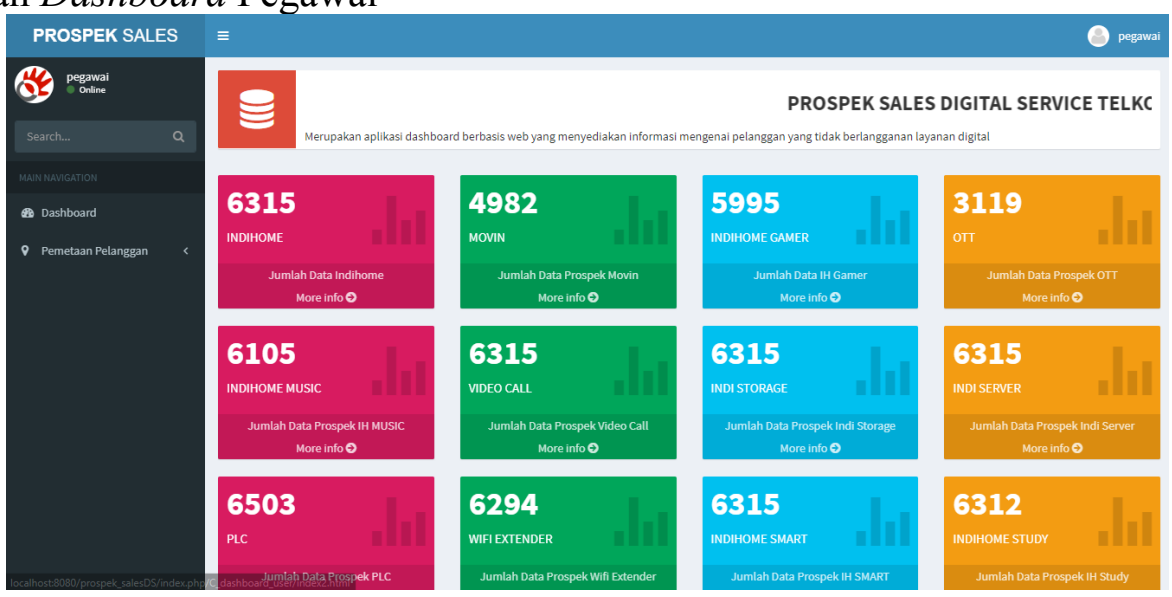

Gambar 10. Halaman Dashboard Pegawai 
Pada Gambar 10 dapat dilihat jumlah pelanggan indihome dan jumlah pelanggan yang tidak berlangganan paket add on seperti Movin, Indihome Gamer, Ott, Indihome Music, dan paket add on lainnya. Pada halaman dashboard pegawai tidak bisa manajemen user kecuali admin.

8. Halaman Paket Add On Pegawai

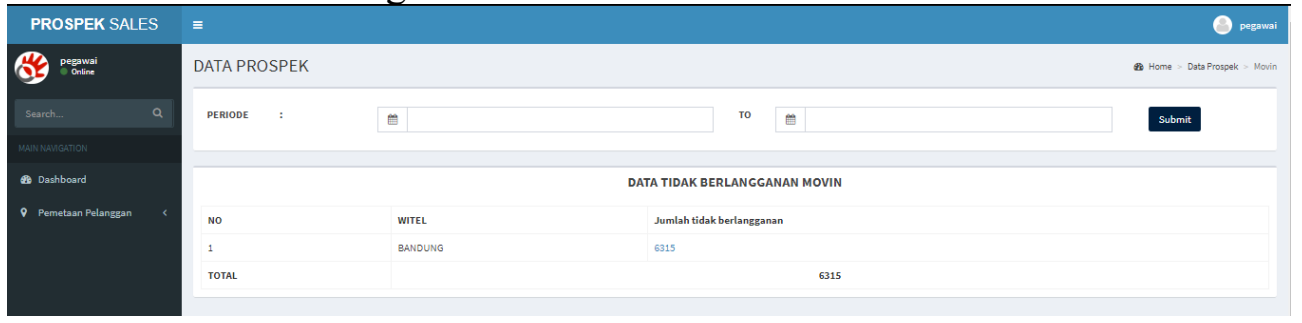

Gambar 11. Halaman Paket Add On Pegawai

Pada Gambar 10 pegawai hanya bisa melihat dan download jumlah pelanggan yang tidak berlangganan paket add On. Apabila jumlah tersebut di klik maka otomatis data ke download.

\section{Kesimpulan}

Aplikasi yang dibangun telah mampu menjawab permasalahan yang dibahas sebelumnya, serta telah mencapai tujuan diantaranya sistem yang telah dibangun dapat melakukan pengolahan data pelanggan indihome dan paket Add On sehingga dapat melihat jumlah pelanggan indihome yang tidak berlangganan dengan paket Add On seperti Movin, Indihome Gamer, Indihome Musik, dan paket lainnya. Jumlah pelanggan yang tidak berlangganan dapat dilihat pada Gambar 4, yaitu halaman dashboard Admin dan Gambar 10 halaman dashboard Pegawai. Selain itu sistem yang telah dibangun ini dapat melihat informasi terkait daerah/wilayah berdasarkan lokasi pelanggan indihome yang belum berlangganan paket $A d d$ On pada peta/maps yang telah ditambahkan pada sistem dengan menggunakan Google Maps API, sehingga dapat dijadikan sebagai sasaran promosi. Peta/Maps dapat dilihat pada Gambar 5 Halaman peta pelanggan. Adapun kekurangan dari aplikasi Prospek Sales ini yaitu tidak adanya data Latitude dan Longitude pelanggan indihome pada saat admin melakukan pemetaan sehingga admin harus menginputkan Latitude dan Longitude secara manual berdasarkan alamat pelanggan indihome. Selain itu belum bisa menambahkan fitur kelola menu paket add on oleh admin, apabila ada paket add on baru pihak admin belum bisa menambahkan paket baru tersebut. Sehingga aplikasi Prospek Sales ini masih butuh pengembangan.

\section{Ucapan Terima Kasih}

Ucapan terima kasih ditujukan kepada PT.Telekomunikasi Indonesia Regional III Jawa Barat yang telah memberikan izin untuk melakukan penelitian serta membantu proses pengumpulan data yang digunakan dalam penelitian.

\section{Daftar Pustaka}

[1] F. Hakim, A. M Ferlina, and Trenggana, "Analisis Strategi Pemasaran Produk Indihome Pt. Telkom Witel Bandung," e-Proceeding Manag., vol. 4, no. 1, pp. 670677 , 2017.

Available: https://repository.telkomuniversity.ac.id/pustaka/files/123867/jurnal_eproc/analisis- 
strategi-pemasaran-produk-indihome-pt-telkom-witel-bandung.pdf. [Accessed: 25Oct-2019]

[2] K. M. P. Artawan, Ferdian, and Wiyono, "Pengukuran Efektivitas Program Promosi UseeTV Telkom Witel Bali Selatan dengan menggunakan Konsep Consumer Decision Model," e-Proceeding Eng., vol. 2, no. 1, pp. 973-979, 2015. Available: https://libraryeproceeding.telkomuniversity.ac.id/index.php/engineering/article/view File/2251/2128. [Accessed: 15-Jan-2020]

[3] M. V. A. Karinda, L. Mananeke, and F. Roring, "Pengaruh Strategi Pemasaran Dan Inovasi Produk Terhadap Kinerja Pemasaran Produk Indihome Pt.Telkom Area Tomohon," J. EMBA J. Ris. Ekon. Manajemen, Bisnis dan Akunt., vol. 6, no. 3, pp. $1568-1577$, 2018 .

Available: https://ejournal.unsrat.ac.id/index.php/emba/article/viewFile/20265/19872. [Accessed: 30-Oct-2019]

[4] D. Syahrul Anwar, N. Suciyono, and Yogi, "Sistem Informasi Geografis Pemetaan Jaringan Pelanggan Indihome Berbasis Web Di Pt . Telkom Cabang Singaparna," VOI Voice Informatics, vol. 6, no. 2, pp. 68-77, 2017. Available: http://voi.stmiktasikmalaya.ac.id/index.php/voi/article/download/96/39. [Accessed: 30-Oct-2019]

[5] A. P. Utomo, F. Nugraha, and A. Setiawan, "Pemetaan Industri Bordir Di Kabupaten Kudus Berbasis Sistem Informasi Geografis Menggunakan Google Map API," $J$. SIMETRIS, vol. 5, no. 2, pp. 161-166, 2014. Available: https://jurnal.umk.ac.id/index.php/simet/article/viewFile/223/222. [Accessed: 16-Jan2020]

[6] N. Prokofyeva and V. Boltunova, "Analysis and Practical Application of PHP Frameworks in Development of Web Information Systems," Procedia Comput. Sci., vol. 104, no. December 2016, pp. 51-56, 2016. Available: http://dx.doi.org/10.1016/j.procs.2017.01.059. [Accessed: 25-Oct-2019]

[7] S. Baghaskara and Suhendra, "Complaint Handling Ticketing Application Web Based Using Codeigniter Framework (Case Study at PT Indosat Ooredoo Tbk Jakarta)," Ijcsmc, vol. 7, no. 12, pp. 14-28, 2018. Available: http://d.researchbib.com/f/7nnJcwp21wYzAioF9xo2AmY3OupTIlp19RMJAyoJWyp wVjZGtiIwqWZGVIZQR4ZGRhpTEz.pdf. [Accessed: 17-Oct-2019]

[8] A. Hanafi, I. M. Sukarsa, and A. A. K. Agung Cahyawan Wiranatha, "Pertukaran Data Antar Database Dengan Menggunakan Teknologi API," Lontar Komput. J. Ilm. Teknol. Inf., vol. 8, no. 1, pp. 22-30, 2017. Available: https://ojs.unud.ac.id/index.php/lontar/article/download/28715/19061. [Accessed: 16Jan-2020]

[9] J. C. Plantin, "The politics of mapping platforms: participatory radiation mapping after the Fukushima Daiichi disaster," Media, Cult. Soc., vol. 37, no. 6, pp. 904-921, 2015.

Available:http://www.academia.edu/download/38631068/Media_Culture_Society 2015-Plantin-904-21.pdf. [Accessed: 14-Oct-2019]

[10] M. F. N. Rizky and Y. Hanifa, "Pengaruh Promosi Dan Harga Terhadap Minat Beli Perumahan Obama Pt. Nailah Adi Kurnia Sei Mencirim Medan Muhammad," J. Manaj. BISNIS, vol. 14, no. 02, pp. 135143,2014.Available:http://jurnal.umsu.ac.id/index.php/mbisnis/article/viewFile/182/1 26. [Accessed: 16-Jan-2020]

[11] D. Abdullah, "Perancangan Sistem Informasi Pendataan Siswa SMP Islam Swasta Darul Yatama Berbasis Web," IJNS - Indones. J. Netw. Secur., vol. 4, no. 1, pp. 39- 
44, 2015. Available:http://ijns.org/journal/index.php/ijns/article/viewFile/1325/1313. [Accessed: 15-Jan-2020]

[12] R. Permana and C. Lesmana, "Pemetaan Kebutuhan Guru di Kecamatan Sungai Kakap Kabupaten Kubu Raya Berbasis Sistem Informasi Geografis (SIG), ' J. Edukasi dan Penelit. Inform., vol. 4, no. 2, pp. 126-131, 2018. Available: http://jurnal.untan.ac.id/index.php/jepin/article/download/27272/75676579702. [Accessed: 16-Jan-2020]

[13] A. Annugerah, I. F. Astuti, and A. H. Kridalaksana, "Sistem Informasi Geografis Berbasis Web Pemetaan Lokasi Toko Oleh-Oleh Khas Samarinda," Inform. Mulawarman J. Ilm. Ilmu Komput., vol. 11, no. 2, pp. 43-47, 2016. Available: https://osf.io/preprints/inarxiv/qf2eg/download. [Accessed: 09-Oct-2019]

[14] A. A. Pradipta, Y. A. Prasetyo, and N. Ambarsari, "Pengembangan Web E-Commerce Bojana Sari Menggunakan Metode Prototype," e-Proceeding Eng., vol. 2, no. 1, pp.1042-1056, 2015.

Available: https://libraryeproceeding.telkomuniversity.ac.id/index.php/engineering/article/down load/2726/2585. [Accessed: 16-Jan-2020]

[15] M. S. Muarie, "Sistem Informasi Perpustakaan SMP Negeri 5 Palembang Menggunakan PHP dan MySQL," J. Tek. Inform. Politek. Sekayu, vol. 1, no. 1, pp. 24-36, 2014.

Available: https://jurnal.polsky.ac.id/index.php/tips/article/download/64/60. [Accessed: 01-Sep2019]

[16] M. Destiningrum and Q. J. Adrian, "Sistem Informasi Penjadwalan Dokter Berbassis Web Dengan Menggunakan Framework Codeigniter (Studi Kasus: Rumah Sakit Yukum Medical Centre)," J. Teknoinfo, vol. 11, no. 2, pp. 30-37, 2017. Available: http://ejurnal.teknokrat.ac.id/index.php/teknoinfo/article/download/24/24. [Accessed: 16-Jan-2020]

[17] K. M. Wibowo, K. Indra, and J. Jumadi, "Sistem Informasi Geografis (SIG) Menentukan Lokasi Pertambangan Batu Bara di Provinsi Bengkulu Berbasis Website," J. Media Infotama, vol. 11, no. 1, pp. 51-60, 2015. Available: https://jurnal.unived.ac.id/index.php/jmi/article/download/252/231. [Accessed: 01Sep-2019] 